International Journal of Health Sciences
Available online at www.sciencescholar.us
Vol. 6 No. 1, April 2022, pages: $196-213$
e-ISSN: 2550-696X, p-ISSN: $2550-6978$
https://doi.org/10.53730/ijhs.v6n1.3766

\title{
Honey, Pollen and Propolis in Therapeutic Treatments for COVID-19
}

\author{
CrossMark \\ Telly Yarita Macías Zambrano a, Johanna Melissa Aguayo Joza ${ }^{\text {b }}$, Gladys Varinia Salazar Cobeña c, \\ Shirley Elizabeth Pizarro Anchundia d, Yesenia Dioselina Macías Zambrano e
}

Manuscript submitted: 9 September 2021, Manuscript revised: 21 December 2021, Accepted for publication: 7 January 2022

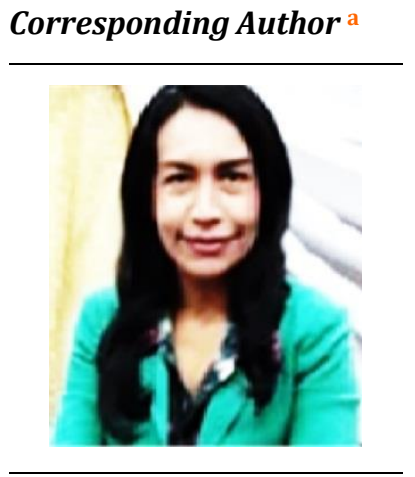

Keywords

apitherapy;

comprehensive health;

COVID-19;

guarantee health;

healthy tissue;

integral wellness;

\begin{abstract}
The study aimed to characterize the therapeutic benefits of honey and other beehive products to determine the feasibility of rural beekeeping production; The research was carried out in 30 apiaries of peasant communities in 7 cantons of the province of Manabí, namely: Portoviejo, Rocafuerte, Bolívar, Santa Ana, Montecristi, Chone and Pichincha; an intentional sampling was applied, the qualitative-quantitative approach, a non-experimental descriptive design; For data collection, the survey technique was applied to beekeepers, the analytical method to perform the analysis of the results of the applied survey. As a result of the bibliographic review, multiple therapeutic benefits of honey, pollen, propolis, apitoxin, royal jelly were obtained, among which their immunomodulatory, antiviral, antimicrobial, antitumor, anti-inflammatory, healing properties, among others specific to each product, stand out. The feasibility of the rural beekeeping activity was determined through the costbenefit analysis whose indicator of 1.95 showed that it is profitable. It was concluded that honey and other products from the hive contribute to preventing, strengthening, and improving the ability to respond to various diseases that afflict human beings, and as a productive activity, it is feasible to implement it to generate income for families.
\end{abstract}

International Journal of Health Sciences (C) 2022.

This is an open access article under the CC BY-NC-ND license (https://creativecommons.org/licenses/by-nc-nd/4.0/).

\section{Contents}

Abstract

1 Introduction.

\footnotetext{
a Asociación Fuerza Apícola Montuvia, Portoviejo, Ecuador

b Universidad Técnica de Manabí, Portoviejo, Ecuador

c Universidad Técnica de Manabí, Portoviejo, Ecuador

d Universidad Técnica de Manabí, Portoviejo, Ecuador

e Dispensario Médico Popular, Portoviejo, Ecuador
} 


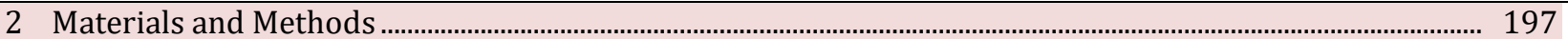

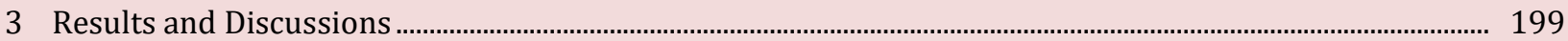

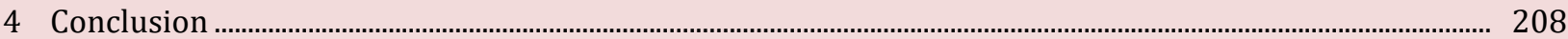

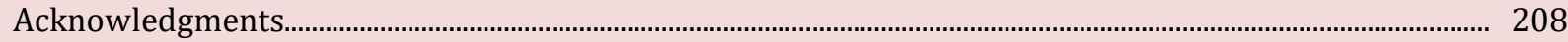

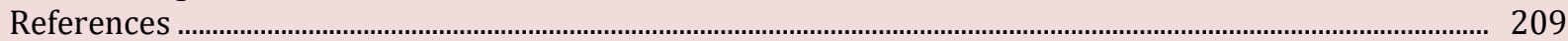

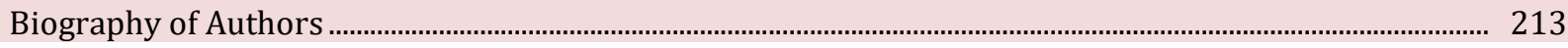

\section{Introduction}

Beekeeping is a very broad scientific issue, which has to do with agriculture, nutrition, medicine, industrial products, and the environment (Saha, 2002). The first record on beekeeping corresponds to Egypt in the year $2400 \mathrm{BC}$, in which the use of hives, handling, and harvesting of honey from honeybees is detailed (Lino, 2002). It is one of the productive activities that has been practiced many centuries ago, in the torrid regions of the planet, and in America especially, countries like Mexico and its Mayan culture, have promoted knowledge from generation to generation, for which it is currently a source of income and employment in rural sectors, acquiring socio-economic relevance (Magaña et al., 2016). This ancient activity that dates back to preColumbian times and promotes the raising of bees for the production of honey, has been spreading in the world whole (Contreras et al., 2018), as well as in countries like Ecuador, due to its climatic and geographical characteristics, the potential for beekeeping is evident; the last beekeeping census carried out by the Ministry of Agriculture and Livestock (2018), shows Figures of 1,760 beekeepers and 19,155 hives, an increase of 6,967 hives in 3 years, estimating a sixteen-fold increase in the number of hives producing honey, according to the study by (Velás quez \& Goestchel, 2019). The practice of rural beekeeping is linked to the knowledge of peasant farmers in a rural territory (Macías, 2018), and is understood as "an agricultural activity that contributes to the protection of the environment and agroforestry production through the pollinating action of bees" (Mancera Rodríguez \& Sánchez Ayala, 2019).

Beekeeping is easily integrated with ecosystems given its nature, which is its habitat, however, it is also practiced in ecosystems damaged by the hand of man to improve them and gradually obtain the economic benefits of their production (FAO, sf). The products of the beekeeping activity, called hive products, include honey as the main one, however, there are others such as propolis, pollen, royal jelly, wax, and apitoxin or honeybee venom (Verde, 2014; Peiren et al., 2005; Naug, 2009). All this noble production, the result of the noble work of honeybees, in particular worker bees, implies numerous benefits for consumers, information that few peasant beekeepers know, due to their rudimentary practices, despite numerous studies in this regard, especially in Mexico and China, they demonstrate the therapeutic efficacy of hive products (Macías, 2021).

When the beekeeper harvests, it means that he collects the honey from the different hives. This practice is a ritual that involves time, dedication, effort, and knowledge, since the products are sensitive, and their proper handling is essential to guarantee their quality (Bøe et al., 2012). On this depends on that you can be successful in your harvest, not only for the quantity but for the quality guaranteed with good beekeeping practices, especially when products such as pollen and propolis are part of the production that beekeepers usually deliver to the farm. social demand for beekeeping production (Zambrano et al., 2020). In this context, the research objective was to characterize the therapeutic benefits of honey and other products from the hive to determine the feasibility of rural beekeeping.

\section{Materials and Methods}

The research was carried out in the province of Manabí, in 7 cantons, namely: Portoviejo, Rocafuerte, Bolívar, Santa Ana, Montecristi, Chone and Pichincha. The province is geographically located at coordinates 10 $03^{\prime} 08^{\prime \prime}$ south latitude and $80^{\circ} 27^{\prime} 02^{\prime \prime}$ west latitude, at 350 masl, it is the second in the Ecuadorian coastal region, and is politically divided into 24 cantons. Figure 1 shows the location of the cantons studied.

Zambrano, T. Y. M., Joza, J. M. A., Cobeña, G. V. S., Anchundia, S. E. P., \& Zambrano, Y. D. M. (2022). Honey, pollen and propolis in therapeutic treatments for COVID-19. International Journal of Health Sciences, 6(1), 196213. https://doi.org/10.53730/ijhs.v6n1.3766 


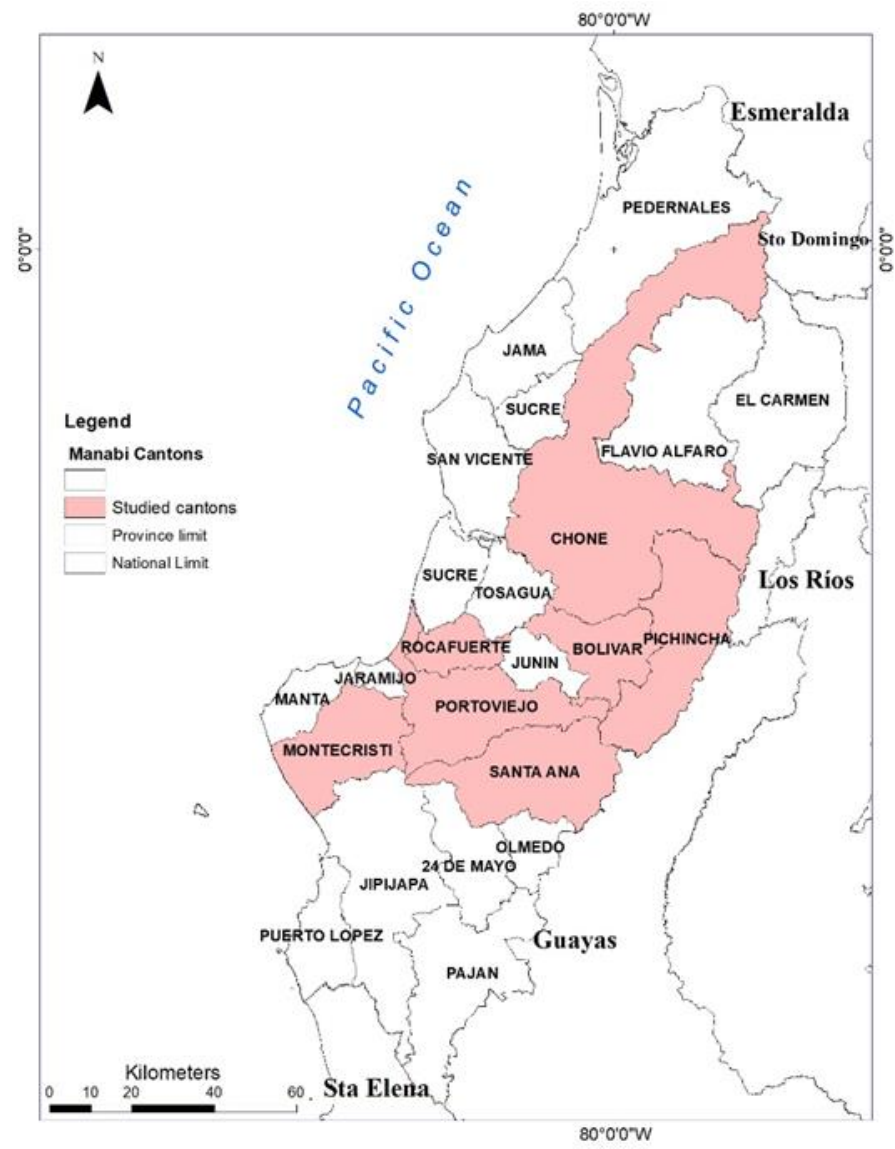

Figure 1. Cantons studied

An intentional sampling was applied at the discretion of the authors, the qualitative-quantitative approach to the research, a non-experimental descriptive design; For data collection, primary information sources were applied, such as the technique of interviewing the expert to determine the recommended doses in the consumption of the products of the hive; the bibliographic review in specialized information sources indexed to recognized databases, managing to investigate 80 sources that include papers, books, reports, and theses, of which 68 were referenced in this document. The survey technique was also applied through a structured questionnaire to beekeepers, the use of the analytical method to carry out the analysis of the feasibility of the production of rural apiaries and the results of the applied survey, whose information was tabulated, processed, and outlined in tables and graphs that detail the findings found. A representative sample of the population of rural apiaries of the Portoviejo canton was taken, based on intentional sampling, at the discretion of the researcher, which corresponds to 30 beekeepers from the Asociación Fuerza Apícola montuvia, which is shown in table 1.

Table 1

Sample of rural apiaries

\begin{tabular}{lc}
\hline Cantons & No. Apiaries \\
\hline Portoviejo & 5 \\
Rocafuerte & 5 \\
Montecristi & 5 \\
Chone & 3 \\
Bolívar & 5 \\
Pichincha & 2 \\
\hline
\end{tabular}




\section{Results and Discussions}

\section{Benefits of honey and other beehive products}

Honey is one of the miracles of nature, one of the blessings that the Divine planted on earth to maintain the balance of vital energy in humanity (Hurtak, 1990), one of its applications is through apitherapy that uses honey and other products from the hive to restore and maintain comprehensive health in humans, evidenced through several studies that denote the welfare of beekeepers, who practice beekeeping, whose incidence of cancer is 10 times lower than common people, they are harmoniously connected with their natural environment, which gives them immunity and resistance to disease (Dussart, 2007).

\section{Honey}

Honey is a sweet, unfermented substance produced by bees (Apis mellifera) that collect and processes nectar from flowers or the secretions of certain plant species. Bees transform and combine this substance with other specific substances of their own that finally store and mature in honeycombs (Schemcke et al., 2016).

The properties of honey provide significant benefits when consumed or used on the skin, on wounds or burns, as a moisturizer or nutrient, among others. Its antimicrobial property reduces contamination of wounds, as it is an antioxidant it reduces reactive oxygen species and the concentration of free radicals that occur in the inflammatory phase of the wound; its anti-inflammatory property reduces inflammation of wounds, prevents the formation of edema by being anti-edematous; reduces pain due to its quality of exudative wounds; debrides eschar and necrotic tissue from burns; stimulates wound closure by forming healthy tissue, given its healing property (Suguna et al., 1993; Velnar et al., 2009; Molan, 2011; Yaghoobi \& Kazerouni, 2013; Oryan et al., 2016). These properties are shown in Figure 2.

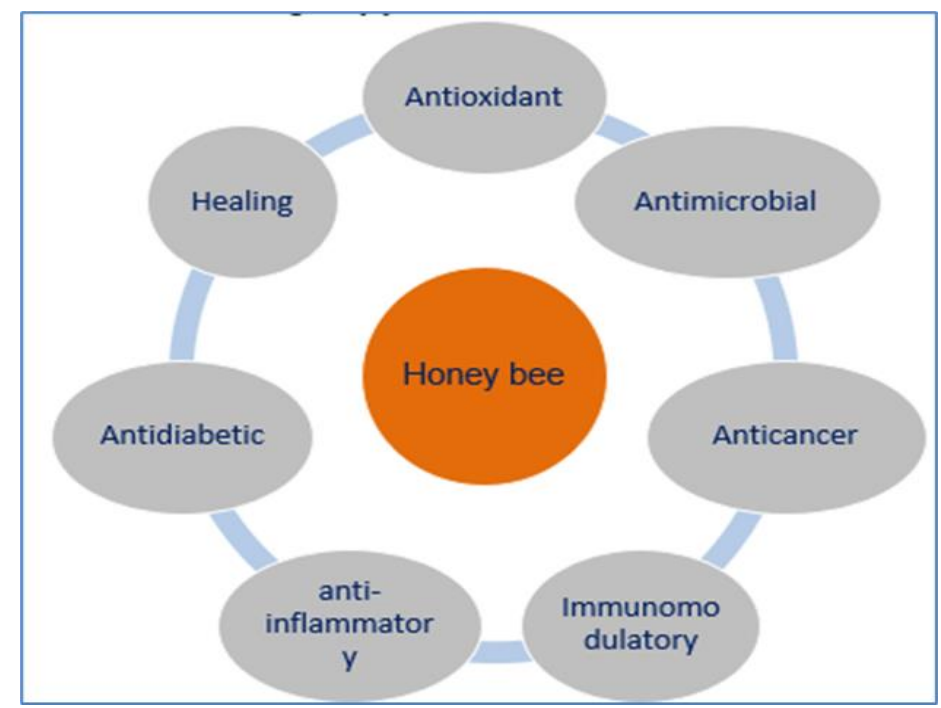

Figure 2. Properties of honey

Source: Otero et al. (2018)

The beneficial properties of honey help restore skin wounds and reduce scabs, minimize contractures and scars in burns, leaving very thin scars (Subrahmanyam, 2007; Tan et al., 2012). Honey components such as hydrogen peroxide promote re-epithelialization, collagen synthesis, capillary formation (Molan, 2001; Rossiter et al., 2010; Nakajima et al., 2013; Boekema et al., 2013; Al-Jadi et al., 2014). Various investigations

Zambrano, T. Y. M., Joza, J. M. A., Cobeña, G. V. S., Anchundia, S. E. P., \& Zambrano, Y. D. M. (2022). Honey, pollen and propolis in therapeutic treatments for COVID-19. International Journal of Health Sciences, 6(1), 196213. https://doi.org/10.53730/ijhs.v6n1.3766 
show that honey acts as a tissue repairer promotes "angiogenesis, granulation, and epithelialization, stimulates lymphocytes and phagocytes, induces the expression of molecular markers for tissue repair and the activation of keratinocytes" (Burlando \& Cornara, 2013). Table 2 characterizes the properties of honey.

Table 2

Characterization of honey

\begin{tabular}{|c|c|}
\hline Property & Description \\
\hline Antimicrobial & $\begin{array}{l}\text { Honey has broad-spectrum antimicrobial activity, controls inflammation } \\
\text { before wound healing, acts effectively as an antibacterial, anti-inflammatory, } \\
\text { antioxidant in the inflammatory stage of wounds (Nejati \& Zahmatkesh, } \\
\text { 2016). The antibacterial properties of honey combat pathogens such as } \\
\text { gram-positive and negative, aerobic, and anaerobic bacteria and multi- } \\
\text { antibiotic resistant bacteria, controlling microbial activity in infected burn } \\
\text { wounds (Saeidinia et al., 2017). }\end{array}$ \\
\hline Immunostimulant & $\begin{array}{l}\text { Honey is immunostimulant given its high content of glycoproteins, all the } \\
\text { antimicrobial actions of honey act as immunostimulants (Molan, 2011), } \\
\text { activating the growth of antibodies, lymphocytes, and cytokines, } \\
\text { strengthening the immune system in people (Subrahmanyam, 2007) }\end{array}$ \\
\hline Healing & $\begin{array}{l}\text { The topical use of honey for the treatment of burns and other wounds } \\
\text { reflects that it is a safe, non-toxic product to also be applied as a dressing on } \\
\text { wounds (García Felipe, 2019). There is no known information on allergies or } \\
\text { glycemia alterations in patients with diabetes mellitus, since allergy to honey } \\
\text { is rare in people, being its topical use ico advisable (Burlando \& Cornara, } \\
\text { 2013). }\end{array}$ \\
\hline Skin debridement & $\begin{array}{l}\text { Its physical and skin debridement properties, due to its high viscosity, } \\
\text { generate a moist environment and a barrier in the wound that promotes the } \\
\text { healing of burns that heal better in these environments (Kaneko, 2015), } \\
\text { ensuring the growth of new epithelial cells that do not suffer rupture due to } \\
\text { the approach of the fibroblasts to the wound, without causing pain when } \\
\text { eliminating the eschar and necrotic tissues caused by the burn (Molan, } \\
\text { 2011). }\end{array}$ \\
\hline Antioxidant & $\begin{array}{l}\text { Its properties and antioxidants reveal that it is effective in combating } \\
\text { oxidative deterioration in the body, due to its phenolic compounds and the } \\
\text { presence of ascorbic acid, amino acids, tocopherols, B complex vitamins, } \\
\text { reductase, selenium, glutathione, dismutase, peptides, superoxide, catalase, } \\
\text { salicylic acid in low concentration and organic acids such as citric, gluconic } \\
\text { and malic acids that enhance the other antioxidants because they are metal } \\
\text { chelates (Tan et al. 2012; Yaghoobi \& Kazerouni, 2013). }\end{array}$ \\
\hline Anti-inflammatory & 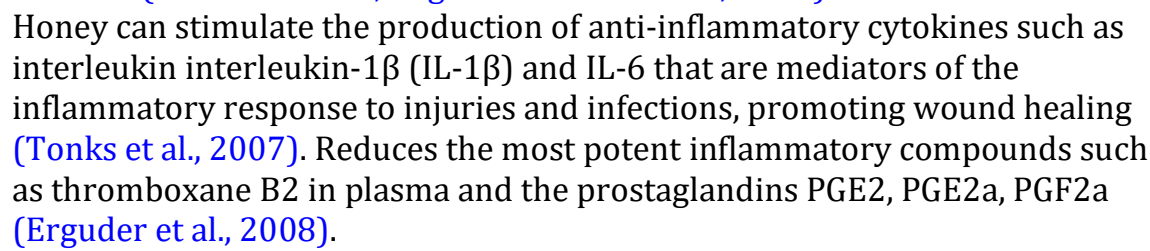 \\
\hline Anticarcinogenic & $\begin{array}{l}\text { It has an anti-proliferative effect in v ytro in bladder cancer cells, according } \\
\text { to several studies (Khan et al., 2018), whose composition of phenolic acids of } \\
\text { caffeic acid induces apoptosis of cancer cells and stops cell growth of the sub } \\
\text { G1 phase of the cancer cell cycle. In cases of metastasis, honey acts against } \\
\text { cancer cells with anti-angiogenic effects in various types of cancer such as } \\
\text { cervical, bone, liver, oral, breast, and bladder (Rao et al., 2016). }\end{array}$ \\
\hline Antidiabetic & $\begin{array}{l}\text { It is an option as a sweetener for diabetic patients due to its } \\
\text { antihyperglycemic effects (Otero et al., 2018), which significantly reduce }\end{array}$ \\
\hline
\end{tabular}


blood glucose levels and have a significant effect on weight improvement (Rao et al., 2016).

The honey must be packaged in glass, away from humidity and dryness, in a neutral environment so that it does not crystallize, in Figure 3, you can see a container with honey packaged in a rural apiary.

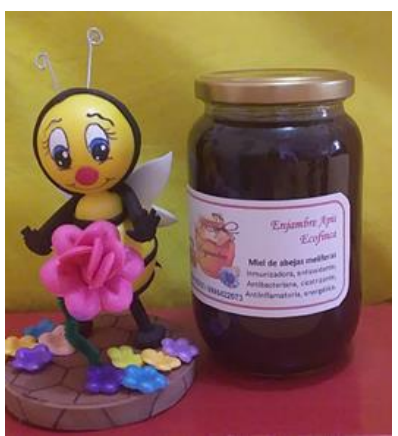

Figure 3. Pure honey of honeybees

Source: Enjambre Apis Ecofinca (2022)

\section{Pollen}

Pollen is a source of protein, minerals, and vitamins considered an excellent protein for humans (Schencke et al., 2016). For its production, worker bee's foragers collect it in its third pair of hind legs from the stamens of the flowers and later deposit it in the cells of the hive's breeding chamber, then the nurse bees compact it to prepare a slurry with honey and saliva known as bee bread that constitutes the food of the larvae for their growth in the hive (Bucaccio, 1996). It is an energizer used as a supplement in sports (Burlando \& Cornara, 2013). Pollen proteins used in the manufacture of honey-based cosmetic products can cause sensitivity to allergic people (Dussart, 2007).

It has an important therapeutic activity and is considered the perfect food because it contains 22 of the essential amino acids for the human body, carbohydrates such as fructose and glucose and lipids, unsaturated fatty acids, vitamins and minerals such as those of group B, vitamin C, E, magnesium, calcium, iron, zinc, and manganese (Frías et al., 2016). It is recommended in the prevention and treatment of diseases such as cardiovascular, osteoarthritis, arthritis, and cancer, due to its content of fatty acids, omega 3, 6, 9 polyunsaturated All the therapeutic benefits of bee pollen are also due to its flavonoid compounds such as quercetin, kaempferol and isorhamnetin up to $5 \%$ of its composition and polyphenols in $0.2 \%$ table 3 shows composition (Sagona et al., 2017).

Table 3

Composition of harvested pollen

\begin{tabular}{lc}
\hline Component & Composition (\%) \\
\hline Proteins & $10-40$ \\
Carbohydrates & $13-55$ \\
Total sugars 28\% & 28 \\
Lipids & $1-19$ \\
Minerals & $3-14$ \\
Fiber & $0.3-20$ \\
Vitamins ACDE MB B2 B3 B6 & 2 \\
B72 etc & \\
Water & $15-30$ \\
\hline \multicolumn{2}{l}{ Source: Taken from (Tvrzicka et al., 2011; Cane, 2020) }
\end{tabular}

Zambrano, T. Y. M., Joza, J. M. A., Cobeña, G. V. S., Anchundia, S. E. P., \& Zambrano, Y. D. M. (2022). Honey, pollen and propolis in therapeutic treatments for COVID-19. International Journal of Health Sciences, 6(1), 196213. https://doi.org/10.53730/ijhs.v6n1.3766 
Pollen is a powerful appetite stimulant, prevents and controls malnutrition, is a source of energy that ends body fatigue, effectively fights anemia, increases the number of red blood cells and the rate of hemoglobin in the human body, and promotes protein synthesis; it functions as an intestinal regulator, improves the appearance of skin and scar tissues by repairing them, also due to its high content of methionine is a regulator of liver activity (Şenel \& Demir, 2018; Münstedt et al., 2019). This wonderful product of the hive is indicated in cases of bone fractures, prostatism, depression, eyestrain, hair loss, impotence, and sexual asthenia and rheumatism (Colombian Society of Apitherapy, 2018).

\section{Propolis}

Propolis is used by bees to protect their hives from invaders such as ants, wasps, and other insects that can take honey, including pests and diseases that can affect the hive, "is a resinous substance, of different colors: yellow, greenish, or dark reddish that bees obtain from plant buds or exudates from some resinous trees such as eucalyptus, pine, and cypress" (Cruz et al., 2020). Bees detach propolis from the trunk and broken branches of trees such as mango and avocado, carrying it in their corbicula (a basket located on their third pair of legs in which they also carry pollen to the hive) to process it by mixing it with pollen, beeswax, enzymes including ashes or earth, giving it more consistency (Vit, 2004; Attamimi et al., 2020).

The bees use it to close the spaces between frames, between covers and cracks of the hives, reduce the entrance and embalm objects or animals that cannot be removed from the hives (mice, snakes). Egyptian priests used it to embalm the mummies of the pharaohs, preserved to this day (including the viscera!). Propolis is the best-known healing agent, one of the best broad-spectrum antibacterial and antifungal products. It is 3.5 times more anesthetic than cocaine and is used in almost all branches of medicine due to its other properties (Dussart, 2007). Figure 4 below shows the propolis packaged in glass droppers.

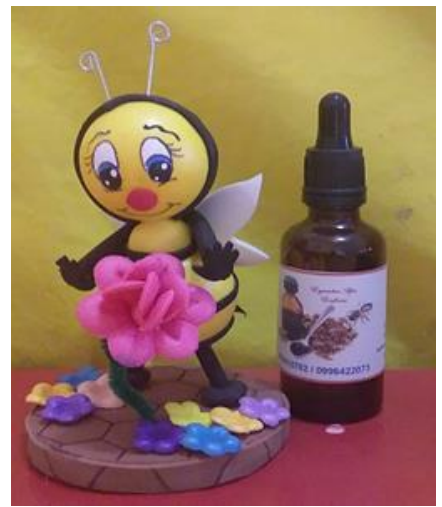

Figure 4. Propolis

Source: Enjambre Apis Ecofinca (2022)

Propolis is made up of more than 200 substances, whose fractions with therapeutic properties are derived from plants and are resins, essential oils, and balsams, which contain powerful bactericides, which make it antibacterial, antiviral, antioxidant, antifungal, anesthetic, anti-inflammatory, healing, antitumor, immunomodulatory, antibiotic due to the presence of 10-hydroxy-2-decenoic acid, proven antitumor agents and molecules that stimulate the immune system (Salmón, 2014). Table 4 details its composition. 
Table 4

Chemical composition of propolis

\begin{tabular}{lc}
\hline Component & Composition (\%) \\
\hline Wax & $20-40$ \\
Resins and aromatic balsams & $40-50$ \\
Essential or volatile oils & $5-10$ \\
Pollen & $4-5$ \\
Organic and mineral substances & 5 \\
Mechanical mixture & $10-30$ \\
\hline
\end{tabular}

Source: (Daleprane \& Abdalla, 2013; Salmón, 2014)

This hive product enhances the response against infectious agents and acts as an immunomodulator. "It can be taken to avoid viral illnesses such as seasonal influenza, which will be important to dissipate before it converges with COVID-19." Propolis can be ingested by all people, except pregnant women. Infants under 2 years of age, people allergic to pollen and propolis itself, or with recent transplant surgery (Cruz et al., 2020).

Wax

Beeswax is the product of their wax glands, it has a low melting point and plastic consistency that give it malleability, it is whitish when it is freshly secreted and acquires a yellowish color as the days go by, even turning dark the longer it goes by Its composition includes flavonoids, esters of C24- C33and acids fatty C18$\mathrm{C} 36$, with melting points in the range of $61-65^{\circ} \mathrm{C}$; it also contains lactones, alcohols, and free acids. It has the advantage of being liposoluble and dissolves with organic solvents (Vit, 2005). It is of two types, the operculum wax, and the honeycomb wax. The first is used by bees to cover the entrance to the breeding and honey production cells, it is clear and fine, and is in demand for the manufacture of cosmetic products. , the most marketed As virgin wax is the wax of the honeycombs, which is found at the bottom of the alveoli and on the walls (Sergeev et al., 2021). The wax contains retinol - vitamin A, essential to strengthen bones, vision, teeth, mucous membranes, and skin, for this reason, it can be chewed together with honey when harvested from the hive (Krell, 1996).

It has a high content of natural lipids, it is hydrophobic, exerting a protective layer that acts as a retainer of water inside the skin, improves it, reinforces its natural barriers and deeply repairs the skin and helps prevent this damage, helps in the healing of wounds, reduces itching and recovers the skin from burns. It has antibacterial agents that combat inflammation related to infection, combined with other natural agents acts as a bacteria inhibitor (Vit et al., 1992). The uses of beeswax are ancient, due to its versatility it is used in cosmetology to make facial creams, ointments, ointments, soaps, capsules, suppositories; in goldsmithing to make crayons, candles, polishes, handicrafts; also in beekeeping, it is used to stamp the frames with wax that are introduced into the hive chambers (Vit, 2004; Akbarov \& Xabilov, 2021).

\section{Apitoxin}

Apitoxin, from the Latin Apis, which means bee, and from the Greek toxikon, which means poison, is also known as medicinal bee venom. It is an aqueous liquid, with acid and bitter taste, transparent, with approximately $88 \%$ water, transparent, with a bitter and acid taste, with a density greater than that of water, which once dehydrated presents a cream coloration that can turn dark brown since some proteins that contain are oxidized (Ioirish, 1995). Its composition of fructose, glucose, phospholipids, and volatile oils cause pain when they evaporate at the site of the sting, but its ashes are rich in magnesium phosphate; contains mainly volatile hydrochloric, formic, and orthophosphoric acids; and enzymes such as phospholipase A, hyaluronidase, lysophospholipase, and a-glucosidase. It contains amino acids and other proteins and peptides such as apamin, secapin, melittin, procamine, mast cell granulation peptide, and a protease inhibitor. Among its active amines it contains histamine, dopamine and norepinephrine (Krell, 1996).

Zambrano, T. Y. M., Joza, J. M. A., Cobeña, G. V. S., Anchundia, S. E. P., \& Zambrano, Y. D. M. (2022). Honey, pollen and propolis in therapeutic treatments for COVID-19. International Journal of Health Sciences, 6(1), 196- 
Apitoxin is a powerful antibiotic, it is used directly by taking the bee to introduce it into the recommended part of the body, this is called api-acupuncture, however, it is also used as api-acupuncture in intradermal injections, pills, ointments, tablets. Although it can cause allergies to people and even death from cyanosis, dyspnea, paralysis, seizures, and others, this depends on the person's sensitivity level, for which an allergy test to Apitoxin should be performed before starting apitherapy (Flowers et al., 2019). The therapy includes up to 10 stings, starting with one on the first day and then gradually increasing with intervals of days, inclusive (Schumacher et al., 1989). Apitoxin therapies are recommended in cases of asthma, epilepsy, arthritis, goiter, multiple sclerosis, malaria, bursitis, intercostal myalgia, hypercholesterolemia, rheumatism, neuritis and neuralgia, ulcers, premenstrual syndrome, among other conditions, which act throughout the body to increase the immune system (Hoffman et al., 1997). It is composed of peptides such as apamin, MCD, melittin, and others, as well as enzymes such as hyaluronidase and phospholipase A2 that fight inflammation (Fáundez Poblete et al., 2011). Table 5 details the composition.

Table 5

Chemical composition of Apitoxin

\begin{tabular}{ll}
\hline Melittin & $\begin{array}{l}\text { Hypotensive, hemolytic and causes contraction of } \\
\text { smooth and striated muscles }\end{array}$ \\
\hline Apamine + melittin & $\begin{array}{l}\text { Increases cortisol } \\
\text { Hyaluronidase }\end{array}$ \\
Increases the permeability of blood vessels \\
Ampromina & Source: Torales et al. (2019)
\end{tabular}

Royal jelly

Royal jelly is a milky substance secreted by the hypopharyngeal glands of young worker bees, from honey and pollen, it is milky, has an acidic taste, a creamy/gelatinous consistency, a pungent smell, and ivory white color (Alcalá Escamilla et al., 2020). It is the food of the queen and the larvae of honeybees (Xue et al., 2017). It consists of a large number of nutrients such as: proteins, lipid components such as 10-hydroxy-trans-2decanoic acid (10H2DA), 10-hydro-xidecanoic acid (10 HDA), carbohydrates such as glucose and fructose; minerals such as $\mathrm{K}, \mathrm{Ca}, \mathrm{Fe}$, and fat-soluble and water-soluble vitamins that promote biological activity related to the presence of flavonoids, lipids, phenolic acids and peptides (Viuda et al., 2017).

It contains many and diverse bioactive components documenting its stimulating, immunomodulatory, hypocholesterolemic, antibacterial, antitumor, hypoglycemic, and antioxidant activity (Nejati \& Zahmatkesh, 2016). To produce JR, bees must consume protein that they obtain naturally from pollen or some other protein source such as brewer's yeast, wheat flour, or legumes (Kaneko, 2015). It has regenerative properties and is a thimiulating agent of metabolism, which is why it is widely used in cosmetology and anti-aging beauty treatments, although scientifically they have not been proven (Hu et al., 2017). Table 6 shows its composition.

Table 6

Composition of royal jelly

\begin{tabular}{|c|c|}
\hline Component & Composition (\%) \\
\hline Water & $70 \%$ \\
\hline Proteins and sugars & 10 \\
\hline $\begin{array}{l}\text { Ethereal extract (mostly 10-hydroxy-2- } \\
\text { decenoic fatty acid) }\end{array}$ & 6 \\
\hline Enzymes & Glucoxidides and phosphatase \\
\hline Minerals & $\mathrm{K}, \mathrm{Na}, \mathrm{Mg}, \mathrm{Ca}, \mathrm{Zn}, \mathrm{Fe}, \mathrm{Cu}, \mathrm{Mn}$ \\
\hline Vitamins & $\begin{array}{l}\text { Folic acid, pantothenic acid, biotin, niacin, } \\
\text { riboflavin, thiamine), inositol and acetylcholine }\end{array}$ \\
\hline Nitrogen dry matter & Enzymes, peptides, and amino acids \\
\hline
\end{tabular}

Source: Alcalá Escamilla et al. (2020) 
Honey syrups

The syrups made with honey and other products of the hive are true enhancers of the human organism, several preparations can be made with honey, pollen, propolis, as well as herbs and vegetables that combined perfectly, help strengthen the immune system and the treatment of respiratory, digestive conditions and strengthen the body, in general.

\section{Honey syrup, pollen, and propolis}

This syrup has the joint properties of honey, pollen, and propolis of the hive that make its antiviral and antibacterial activity, and its chemical composition of phenols such as the phenethyl ester of caffeic acid act on the viral polymerase is an enzyme that replicates the genetic material of COVID-19 that makes it a powerful antimicrobial, and flavonoids that in turn contain antioxidants such as pinocembrin, an effective antiviral, also works as an auxiliary and complementary treatment in the prevention and treatment of viral conditions such as COVID-19 (Kurtieva et al., 2021). The syrup is indicated for children, adults, and older adults, except children under 2 years of age, people allergic to pollen and propolis, or with recent transplant surgeries (Cruz et al., 2020). In Figure 5 you can see the syrup.

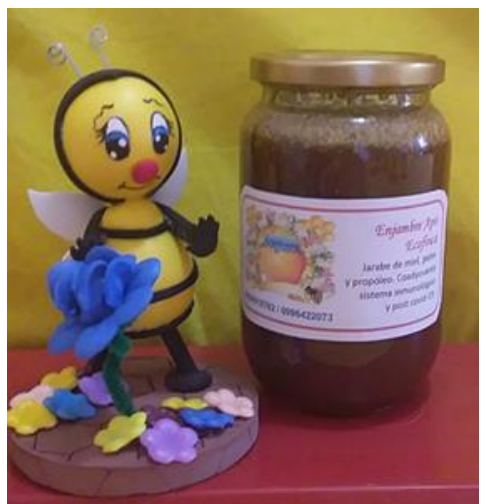

Figure 5. Syrup made with honey, pollen, and propolis Source: Enjambre Apis Ecofinca (2022)

This combination is used for post-COVID-19 treatment, effectively in children, adolescents, youth, adults, and older adults. It is an adjuvant to combat anemia, depression, works as a nutritional and energy supplement, strengthens the immune system (Bravomalo, 2022). The way to consume it is preferably in the mornings, while fasting, for adults, 1 tablespoon, especially when there is a weakness due to anemia, depression, and mood alterations (Macías, 2022; Widana et al., 2021).

Syrup of honey, garlic, onion, and ginger

When the climate changes for the winter, low temperatures influence people and are prone to respiratory conditions such as the common cold, it is in these circumstances that the products of the hive are recommended (PAHO, 2021) to treat symptoms caused by influenza viruses and subtypes, coronavirus (CoV) (Vit, 2004). The syrup of honey, onion, garlic, and ginger acts as a defender of the immune system, protects it, strengthens it, and helps it to face respiratory conditions due to the presence of viruses (Bosch, 2004), has an expectorant and antitussive effect, calms cough and has no adverse effects, is very beneficial for children, young people, and adults, although it is not advisable in children under one year, since honey should not be consumed before one year of age (Ibanez, 2015). In Figure 6 you can see it.

Zambrano, T. Y. M., Joza, J. M. A., Cobeña, G. V. S., Anchundia, S. E. P., \& Zambrano, Y. D. M. (2022). Honey, pollen and propolis in therapeutic treatments for COVID-19. International Journal of Health Sciences, 6(1), 196- 


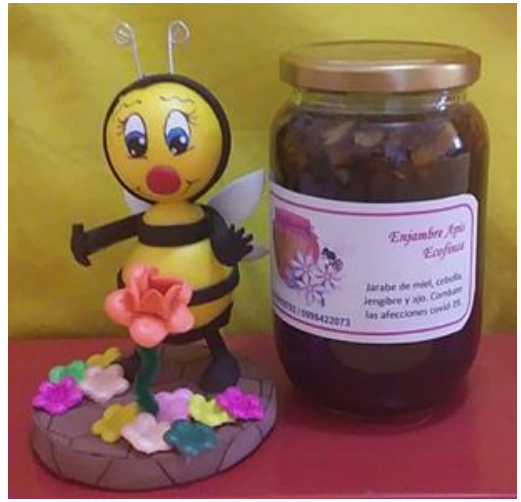

Figure 6. Syrup made with honey, pollen, and propolis Source: Enjambre Apis Ecofinca (2022)

1 tablespoon is recommended on an empty stomach in case of cold, allergies, and as a prevention for 7 days, and 3 to 4 spoons daily, 1 before each meal, in case of flu or COVID-19 (Macías, 2022).

\section{Feasibility of beekeeping production}

As a result of the survey applied to beekeepers in the sample, previous investments were identified to implement a rural apiary with a minimum of one hive consisting of the brood chamber and a storage chamber. production, also known as rising, is made up of 10 frames with wax in turn, which is where the bees deposit the honey collected from the flowers. In addition to the hive, the complete equipment that the beekeeper will use is required, consisting of thick cloth overalls, the veil that consists of a helmet with wings from which the protective veil of the face falls to which it is tied; the smoker to generate smoke that will keep the bees away when the honey is harvested; the hand lever to hold the frames filled with wax; a metal sifter to separate the honey from the remains of wax caused by extraction; various elements such as knife, tongs; glass or plastic containers for packaging honey. Figure 7 details the fixed investments incurred for the implementation of a rural apiary with a minimum of one hive with a riser.

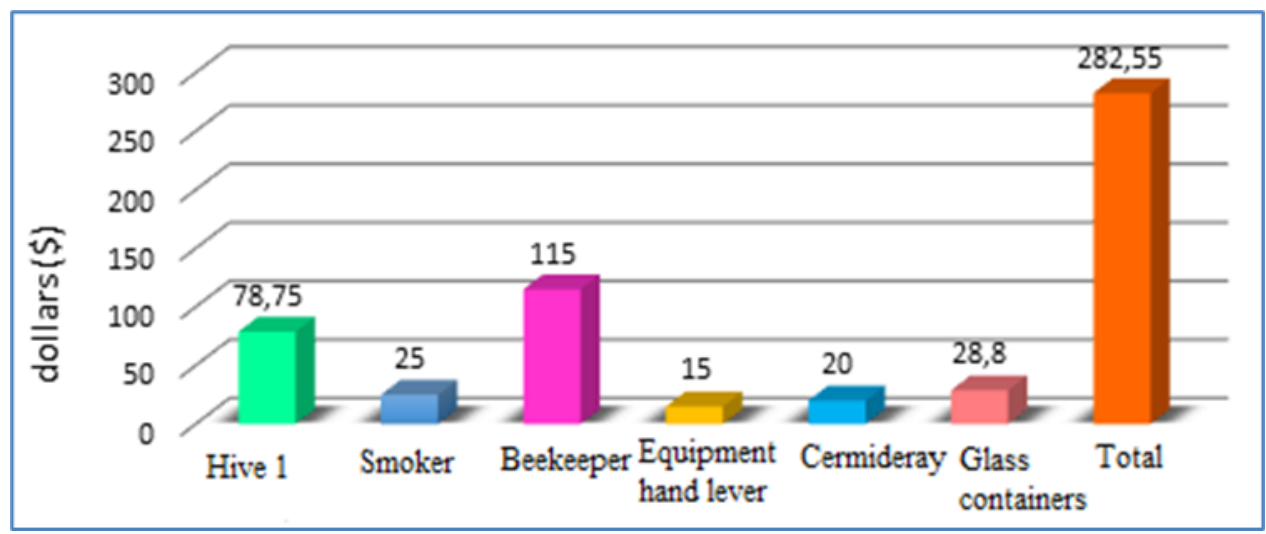

Figure 7. Investments

As can be seen, the fixed investments amount to $\$ 282.55$, a representative value for a farmer who begins to venture into rural beekeeping, however, it should be considered that the first harvest of honey would produce an average of $12 \mathrm{~L}$ of honey and an approximate of 700 grams of pollen, as can be seen in Figure 8 below, which shows the estimated annual sales per hive. 


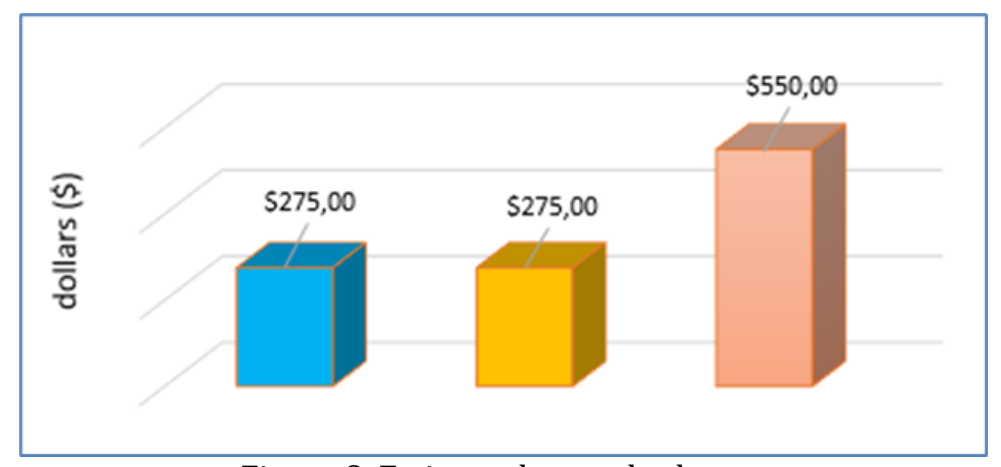

Figure 8. Estimated annual sales

According to Figure (7), the estimated annual sales amount to $\$ 275.00$, which include the sale of honey and pollen, without considering other products from the hive that can also be extracted, such as própolis, this in the first harvest, however, and depending on the annual flowering, there are generally 2 harvests in the year, which would represent another $\$ 275.00$, which would add up to a total of 550.00 in the year per hive. Considering the initial investment of $\$ 282.55$, the recovery factor of the invested capital is immediate, in the first harvest it is possible to recover $97.3 \%$ of the total investment, being able to recover the entire investment, except for certain support elements. In the beekeeping activity and changing glass containers for plastic as it is cheaper since glass containers were considered in this study. In such a way that, to determine the feasibility of beekeeping production, the benefit-cost relationship was applied, considering the following equation 1.

$$
B C=\sum B / \sum C
$$

In Figure 9 the investments and the estimated sales generate the indicator of 1.95 of the benefit-cost ratio.

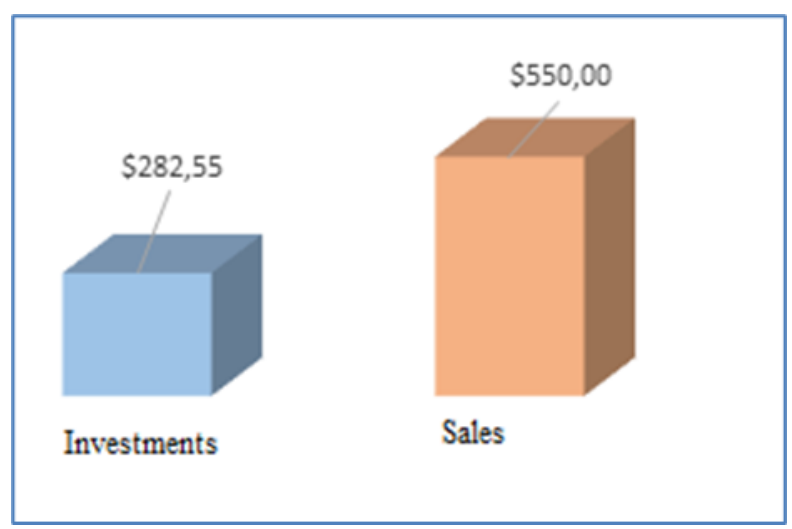

Figure 9. Benefit-cost

This indicator of 1.95, which exceeds 1 , according to the literature reviewed regarding the cost-benefit in Zambrano et al. (2020), refers that the investment is feasible to implement, that the business is profitable and generates economic gains for the investor; that the rural beekeeping activity pays economic benefits to peasant farmers, becoming a viable alternative and an eco-friendly complement to traditional agriculture. These results coincide with Falquez Chávez (2014); Perdomo Velandia \& Posso Zuñiga (2016); that refers to beekeeping as a feasible agricultural and productive activity, which can improve the quality of family life, since it does not require many resources to start it, for which the desirable financial purposes can be achieved for those who undertake, with responsibility in addition.

Zambrano, T. Y. M., Joza, J. M. A., Cobeña, G. V. S., Anchundia, S. E. P., \& Zambrano, Y. D. M. (2022). Honey, pollen and propolis in therapeutic treatments for COVID-19. International Journal of Health Sciences, 6(1), 196- 
Likewise, the study by Londoño Torres \& Corredor Urrego (2020), concludes the viability of honey production for farmers, which also contributes to the environmental component, due to pollination that in turn promotes horticultural and forage production in the study, bringing profits to small farmers, since honey has a natural demand. Magaña et al. (2016) also determine that beekeeping is profitable and can be carried out by peasant farmers, a reason why rural beekeeping is in a process of revaluation and strengthening for these sectors in Mexico.

For his part, Barragán Rivera (2014) in his study, establishes that beekeeping production systems bring some benefits to farmers, especially in environmental and economic aspects, but that they also provide product support to beekeeping, agriculture, to agricultural activity, in which the peasantry is maintained, and which persists over time, contributing to the improvement of their family economies.

Contreras et al. (2016), in their study, deduces the price of honey produced in rural apiaries in Peru, which ranges between 30 and 40 soles, which would be equivalent to an average of 9.10 dollars, which corresponds to less than half the price of $1 \mathrm{~L}$ of honey in Manabi communities. Likewise, Contreras et al. (2018), determine that "the profitability of the beekeeping activity is determined by the production costs and the income received from the sale of honey. The income depends on the amount produced and the sale price of the honey", which corresponds to the present findings, in which it can be evidenced that the production of a single hive generates economic income and profit for the producers, taking into account a sale price of a liter of honey at $\$ 20$, which has not changed for a decade ago, according to the survey of Manabí beekeepers, a price established by the newly organized beekeeping community, in which the nascent beekeepers can support of the rural communities of the province of Manabí.

\section{Conclusion}

The practice of beekeeping in rural areas is an alternative to improve peasant family economies, it is profitable, has low investment, and in the first harvest of honey the initial capital investment for the operation of the hive is recovered, demonstrating the feasibility of beekeeping production, and it is also an eco-friendly option to strengthen agricultural ecosystems, the endemic flora, the surrounding vegetation, the harmony between man and nature, because its practice returns to the beekeeper, the understanding and value for his natural environment.

There are many benefits that the products of the hive bring with them, and the numerous studies on the subject demonstrate this, however, in the current times, when the entire planet is going through severe changes that entail potential impacts on the health and well-being of the inhabitants, it is necessary to take into account the alternative products that nature shares with us, for the human being requires to be well, in mind, body, and spirit, it is thus, that the work of honey bees is substantial and vital, to guarantee health and food. This work is a small contribution to show that the love for harmonious practices with Mother Earth as the rural beekeeping of those who preceded us in this planetary microsphere, is one of the eco-friendly options to sustain the own life and the natural environment of all forms of life that coexist with humans.

\section{Acknowledgments}

Our sincere thanks to the staff of the Dra. Yesenia Macías Zambrano popular medical clinic in Portoviejo, Ecuador, Dra. Yesenia Macías, Lcda. Beatriz Mera, Lcda. Marlene Macias and Econ. Emerson Mend oza, for the valuable information shared to develop this research. To the directors of the Montuvia Beekeeping Force Association of Manabí, Ecuador, Ing. Leida Morán Vega, Ing. Juan Carlos Vélez Vera, Ing. Miguel Bravomalo and Ing. Walter Bravomalo, for all the openness provided to collect field information with the associated beekeepers from various cantons of the province. We thank the anonymous reviewers for their valuable comments on the previous version of the document. To the IJHS magazine for considering this small contribution to the well-being of peasant communities and society, for its publication. 


\section{References}

Akbarov, A. N., \& Xabilov, D. N. U. (2021). The condition of the oral cavity in patients who have had a viral infection COVID-19. International Journal of Health \& Medical Sciences, 4(4), 381-383. https://doi.org/10.21744/ijhms.v4n4.1796

Alcalá Escamilla, KI, Betancur Ancona, DA, Acevedo Fernández, JJ, Nuñez Aragón, PN, \& Moguel Ordóñez, YB (2020). Antioxidant activity of royal jelly obtained from colonies feeded with two different protein supplements.

Al-Jadi, A. M., Enchang, F. K., \& Yusoff, K. M. (2014). The effect of Malaysian honey and its major components on the proliferation of cultured fibroblasts. Turkish journal of medical sciences, 44(5), 733-740.

Attamimi, H. R. ., Lestari, Y. ., Situmorang, B. . H. L. ., Antari, G. Y. ., \& Nugrawati, N. . (2020). Application of habituation method in germas interventionsin: the pandemic time COVID-19. International Journal of Health \& Medical Sciences, 3(1), 98-104.

Barragán Rivera, M. Á. (2014). Apicultura campesina una alternativa para el desarrollo rural en Ocamonte, Santander.

Bøe, T., Hysing, M., Stormark, K. M., Lundervold, A. J., \& Sivertsen, B. (2012). Sleep problems as a mediator of the association between parental education levels, perceived family economy and poor mental health in children. Journal of Psychosomatic Research, 73(6), 430-436. https://doi.org/10.1016/j.jpsychores.2012.09.008

Boekema, B. K. H. L., Pool, L., \& Ulrich, M. M. W. (2013). The effect of a honey based gel and silver sulphadiazine on bacterial infections of in vitro burn wounds. Burns, 39(4), 754-759. https://doi.org/10.1016/j.burns.2012.09.008

Bosch, Á. (2004). SARS, una neumonía atípica de etiología desconocida. Offarm: farmacia y sociedad, 23(1), 6064.

Bravomalo, M. (2022). Benefits of syrups made with pure honey from honey bees. (T. Macías, Interviewer)

Bucaccio, P. (1996). Nutrition and Fitness Programs-An Integral Component of Cigna Corporation's Award Winning Worksite Wellness Initiative. Journal of the American Dietetic Association, 96(9), A65. https://doi.org/10.1016/S0002-8223(96)00536-6

Burlando, B., \& Cornara, L. (2013). Honey in dermatology and skin care: a review. Journal of cosmetic dermatology, 12(4), 306-313.

Cane, J. H. (2000). Pollen nutritional content and digestibility for animals. Pollen and pollination, 187-209.

Contreras-Uc, LC, Magaña-Magaña, MA, \& Sanginés-García, JR (2018). Technical and socioeconomic characteristics of beekeeping in Mayan communities of the Central Coast of Yucatan. University Act , 28 (1), 77-86.

Cruz, T., Gonzalez, M., Garcia, G., \& Soto, C. (2020). It has propolis auxiliary properties against COVID-19. Mexico: National Autonomous University of Mexico.

Daleprane, J. B., \& Abdalla, D. S. (2013). Emerging roles of propolis: antioxidant, cardioprotective, and antiangiogenic actions. Evidence-based complementary and alternative medicine, 2013.

Dussart, D. (2007). Elaboración de subproductos de la miel y la colmena. Nicaragua: Cooperación austriaca para el desarrollo, IICA, ECULCAN.

Erguder, B. I., Kilicoglu, S. S., Namuslu, M., Kilicoglu, B., Devrim, E., Kismet, K., \& Durak, I. (2008). Honey prevents hepatic damage induced by obstruction of the common bile duct. World Journal of Gastroenterology: WJG, 14(23), 3729.

Falquez Chávez, J. C. (2014). Factibilidad de producir y comercializar miel de abeja en la ciudad de Guayaquil.

Faúndez Poblete, W., Narváez Carrasco, C. G., \& Burgos Arias, A. (2011). Efecto antiinflamatorio de apitoxina de Apis mellifera sobre prostaglandina E2 del fluido crevicular gingival de pacientes con y sin enfermedad periodontal, sometidos a apiterapia: ensayo preliminar. Revista clínica de periodoncia, implantología y rehabilitación oral, 4(2), 64-68.

Flowers, E., Brogi, M., Rauscher, E., Kempton, E. M. R., \& Chiavassa, A. (2019). The high-resolution transmission spectrum of HD 189733b interpreted with atmospheric Doppler shifts from three-dimensional general circulation models. The Astronomical Journal, 157(5), 209.

Frias, B. E. D., Barbosa, C. D., \& Lourenço, A. P. (2016). Pollen nutrition in honey bees (Apis mellifera): impact on adult health. Apidologie, 47(1), 15-25.

Zambrano, T. Y. M., Joza, J. M. A., Cobeña, G. V. S., Anchundia, S. E. P., \& Zambrano, Y. D. M. (2022). Honey, pollen and propolis in therapeutic treatments for COVID-19. International Journal of Health Sciences, 6(1), 196- 
García Felipe, S. (2019). La miel como alternativa a los tratamientos tópicos en el proceso de curación de quemaduras, heridas y úlceras. Ene, 13(1).

Hoffmann, A., Vieths, S., \& Haustein, D. (1997). Biologic allergen assay for in vivo test allergens with an in vitro model of the murine type I reaction. Journal of Allergy and Clinical Immunology, 99(2), 227-232. https://doi.org/10.1016/S0091-6749(97)70101-5

Hu, F. L., Bíliková, K., Casabianca, H., Daniele, G., Salmen Espindola, F., Feng, M., ... \& Zhou, J. H. (2019). Standard methods for Apis mellifera royal jelly research. Journal of Apicultural Research, 58(2), 1-68.

Hurtak, J. (1990). Nuestra herencia superior. California: Los Gatos.

Ibanez, E. (2015). It's Health. Obtained from Consumption of propolis and honey strengthens the immune system.

Ioirish, N. (1995). Las Abejas, Farmacéuticas Aladas. Moscú: Editorial Mir.

Kaneko, T. (2015). Anti-oxidative activity of royal jelly glycation products. Glycative Stress Research, 2(3), 108113.

Khan, S. U., Anjum, S. I., Rahman, K., Ansari, M. J., Khan, W. U., Kamal, S., ... \& Khan, H. U. (2018). Honey: Single food stuff comprises many drugs. Saudi journal of biological sciences,25(2), 320-325. https://doi.org/10.1016/j.sjbs.2017.08.004

Krell, R. (1996). Value-added products from beekeeping (No. 124). Food \& Agriculture Org..

Kurtieva, S., Nazarova, J., \& Mullajonov, H. (2021). Features of endocrine and immune status in adolescents with vegetative dystonia syndrome. International Journal of Health Sciences, 5(2), 118-127. https://doi.org/10.29332/ijhs.v5n2.1332

Lino, F. (2002). Study of the quality of honey from the bee Apis mellifera L. marketed in Tegucigalpa, Honduras.

Londoño Torres, L. E., \& Corredor Urrego, Y. T. (2020). Análisis de factibilidad para la implementación de una cooperativa rural de producción apícola en la vereda el tigre, municipio de Vergara Cundinamarca.

Macías, T. (2018). Análisis comparativo de la producción orgánica y convencional de teobroma cacao [Tesis de Maestría, Universidad Técnica de Manabí].

Macías, T. (2021). Una visión ancestral a los saberes montuvios de la campiña manabita. Experiencias, parte I. Ecuador: Grupo Compás.

Macías, T., Bravo, T., Moreira, V. (2020). Quality parameters of honeybee apis mellifera in apiaries of the rural area manabita, Ecuador. Palarch's Journal Of Archaeology of Egypt/ Egyptology, 17(7), 13054-13062. https://archives.palarch.nl/index.php/jae/article/view/5050

Macías, Y. (2022). Recomendaciones sobre la toma de jarabes a base de miel. (T. Macías, Entrevistador)

Magaña Magaña, M. A., Tavera Cortés, M. E., Salazar Barrientos, L. L., \& Sanginés García, J. R. (2016). Productividad de la apicultura en México y su impacto sobre la rentabilidad. Revista mexicana de ciencias agrícolas, 7(5), 1103-1115.

Mancera Rodríguez, D. A., \& Sánchez Ayala, S. A. (2019). Propuesta: apicultura como estrategia de gestión del servicio ecosistémico de polinización en dos fincas apícolas en los municipios de Guasca y Guatavita, Cundinamarca.

Molan, P. (2001). Why honey is effective as a medicine: 2. The scientific explanation of its effects. Bee world, 82(1), 22-40.

Molan, P. C. (2011). The evidence and the rationale for the use of honey as a wound dressing. Wound Practice \& Research: Journal of the Australian Wound Management Association, 19(4).

Münstedt, K., Funk, D., Riepen, T., Berkes, E., \& Hübner, J. (2019). Acceptance of apitherapeutic methods in patients consulting general physicians or gynaecologists. Complementary therapies in Clinical Practice, 35 , 154-157. https://doi.org/10.1016/j.ctcp.2019.02.005

Nakajima, Y., Nakano, Y., Fuwano, S., Hayashi, N., Hiratoko, Y., Kinoshita, A., ... \& Nakatani, T. (2013). Effects of three types of Japanese honey on full-thickness wound in mice. Evidence-Based Complementary and Alternative Medicine, 2013.

Naug, D. (2009). Nutritional stress due to habitat loss may explain recent honeybee colony collapses. Biological Conservation, 142(10), 2369-2372. https://doi.org/10.1016/j.biocon.2009.04.007

Nejati, V., Zahmatkesh, E., \& Babaei, M. (2016). Protective effects of royal jelly on oxymetholone-induced liver injury in mice. Iranian Biomedical Journal, 20(4), 229.

Noriega Salmón, V. (2014). El propóleo, otro recurso terapéutico en la práctica clínica. 
Oryan, A., Alemzadeh, E., \& Moshiri, A. (2016). Biological properties and therapeutic activities of honey in wound healing: A narrative review and meta-analysis. Journal of tissue viability,25(2), 98-118. https://doi.org/10.1016/j.jtv.2015.12.002

Otero, A., Salinas, J., \& Águila, K. (2018). Propeidades curativas de la miel, un edulcorante natural proveniente de los polinizadores naturales de las plantas. Puebla: Benemérita Universidad Autónoma de Puebla.

Peiren, N., Vanrobaeys, F., de Graaf, D. C., Devreese, B., Van Beeumen, J., \& Jacobs, F. J. (2005). The protein composition of honeybee venom reconsidered by a proteomic approach. Biochimica et Biophysica Acta (BBA)-Proteins and Proteomics, 1752(1), 1-5. https://doi.org/10.1016/j.bbapap.2005.07.017

Perdomo Velandia, MR, \& Posso Zuñiga, MA (2016). Feasibility study for the creation of a beekeeping company in the municipality of Arauca.

Rao, P. V., Krishnan, K. T., Salleh, N., \& Gan, S. H. (2016). Biological and therapeutic effects of honey produced by honey bees and stingless bees: a comparative review. Revista Brasileira de Farmacognosia, 26, 657-664.

Rossiter, K., Cooper, A. J., Voegeli, D., \& Lwaleed, B. A. (2010). Honey promotes angiogeneic activity in the rat aortic ring assay. journal of wound care, 19(10), 440-446.

Saeidinia, A., Keihanian, F., Lashkari, A. P., Lahiji, H. G., Mobayyen, M., Heidarzade, A., \& Golchai, J. (2017). Partial-thickness burn wounds healing by topical treatment: a randomized controlled comparison between silver sulfadiazine and centiderm. Medicine, 96(9).

Sagona, S., Pozzo, L., Peiretti, P. G., Biondi, C., Giusti, M., Gabriele, M., ... \& Felicioli, A. (2017). Palynological origin, chemical composition, lipid peroxidation and fatty acid profile of organic Tuscanian beepollen. Journal of Apicultural Research, 56(2), 136-143.

Saha, J. C. (2002). Apicultura para el desarrollo rural-su potencial y apicultura contra la pobreza-desde la perspectiva de Bangladesh. Comisión permanente de Apicultura para el desarrollo rural. Bangladesh.

Schencke, C., Vásquez, B., Sandoval, C., \& del Sol, M. (2016). El rol de la miel en los procesos morfofisiológicos de reparación de heridas. International Journal of Morphology, 34(1), 385-395.

Schumacher, M. J., Schmidt, J. O., \& Egen, N. B. (1989). Lethality of'killer'bee stings. Nature, 337(6206), 413425.

Şenel, E., \& Demir, E. (2018). Bibliometric analysis of apitherapy in complementary medicine literature between 1980 and 2016. Complementary therapies in clinical practice,31, 47-52. https://doi.org/10.1016/j.ctcp.2018.02.003

Sergeev, V. A., Glukhov, A. A., Sorokin, A. S., Zhuchkov, S. A., Gorokhov, A. V., \& Troshkina, E. N. (2021). Clinicalfunctional and morphological parameters of purulonecrotic foci healing in diabetic foot syndrome using programmable sanitation technologies. International Journal of Health Sciences, 5(3), 260-275. https://doi.org/10.53730/ijhs.v5n3.1495

Subrahmanyam, M. (2007). Topical application of honey for burn wound treatment-an overview. Annals of burns and fire disasters, 20(3), 137.

Suguna, L., Chandrakasan, G., Ramamoorthy, U., \& Joseph, K. T. (1993). Influence of honey on biochemical and biophysical parameters of wounds in rats. Journal of Clinical Biochemistry and Nutrition, 14(2), 91-99.

Tan, M. K., Hasan Adli, D. S., Tumiran, M. A., Abdulla, M. A., \& Yusoff, K. M. (2012). The efficacy of Gelam honey dressing towards excisional wound healing. Evidence-Based Complementary and Alternative Medicine, 2012.

Tonks, A. J., Dudley, E., Porter, N. G., Parton, J., Brazier, J., Smith, E. L., \& Tonks, A. (2007). A 5.8-kDa component of manuka honey stimulates immune cells via TLR4. Journal of leukocyte biology, 82(5), 1147-1155.

Torales, EF, Barajas, S. Á., Haramati, J., Paredes, MVP, \& Roa, RIL (2019). Effect of apitoxin treatment (Apis mellifera venom) on the survival of BALB/c mice with L-5178-Y murine lymphoma. e-CUCBA , (11), 18-22.

Tvrzicka, E., Kremmyda, L. S., Stankova, B., \& Zak, A. (2011). Fatty acids as biocompounds: their role in human metabolism, health and disease-a review. part 1: classification, dietary sources and biological functions. Biomedical Papers of the Medical Faculty of Palacky University in Olomouc, 155(2).

Velásquez, D., \& Goetschel, L. (2019). Determinación de la calidad físico-química de la miel de abeja comercializada en Quito y comparación con la miel artificial. Enfoque UTE, 10(2), 52-62.

Velnar, T., Bailey, T., \& Smrkolj, V. (2009). The wound healing process: an overview of the cellular and molecular mechanisms. Journal of International Medical Research, 37(5), 1528-1542.

Verde, M. M. (2014). Apicultura y seguridad alimentaria. Revista Cubana de Ciencia Agrícola, 48(1), 25-31.

Vit, P. (2004). Beehive products collected and processed by bees: Honey, pollen and propolis. Magazine of the National Institute of Hygiene Rafael Rangel, 35(2), 32-39.

Zambrano, T. Y. M., Joza, J. M. A., Cobeña, G. V. S., Anchundia, S. E. P., \& Zambrano, Y. D. M. (2022). Honey, pollen and propolis in therapeutic treatments for COVID-19. International Journal of Health Sciences, 6(1), 196- 
Vit, P. (2005). Hive products secreted by bees: Beeswax, royal jelly and bee venom. Magazine of the National Institute of Hygiene Rafael Rangel, 36(1), 35-42.

Vit, P., Roldan, S., Tamer, E., \& Olivo de Acosta, E. (1992). Detection of adulterations in beeswax commercialization in Venezuela. Rev. Inst. Nac. Hig, 23-7.

Viuda-Martos, M., Pérez-Alvarez, J. A., \& Fernández-López, J. (2017). Royal jelly: Health benefits and uses in medicine. In Bee Products-Chemical and Biological Properties (pp. 199-218). Springer, Cham.

Widana, I.K., Sumetri, N.W., Sutapa, I.K., Suryasa, W. (2021). Anthropometric measures for better cardiovascular and musculoskeletal health. Computer Applications in Engineering Education, 29(3), 550561. https://doi.org/10.1002/cae.22202

Xue, X., Wu, L., \& Wang, K. (2017). Chemical composition of royal jelly. In Bee products-chemical and biological properties (pp. 181-190). Springer, Cham.

Yaghoobi, R., \& Kazerouni, A. (2013). Evidence for clinical use of honey in wound healing as an anti-bacterial, anti-inflammatory anti-oxidant and anti-viral agent: a review. Jundishapur journal of natural pharmaceutical products, 8(3), 100.

Zambrano, T. Y. M., Gámez, M. R., Vera, T. V. M., Macías, R. B. M., \& Mero, T. B. B. (2020). Quality parameters of honeybee apis mellifera in apiaries of the rural area manabita ecuador. PalArch's Journal of Archaeology of Egypt/Egyptology, 17(7), 13054-13062. 


\section{Biography of Authors}

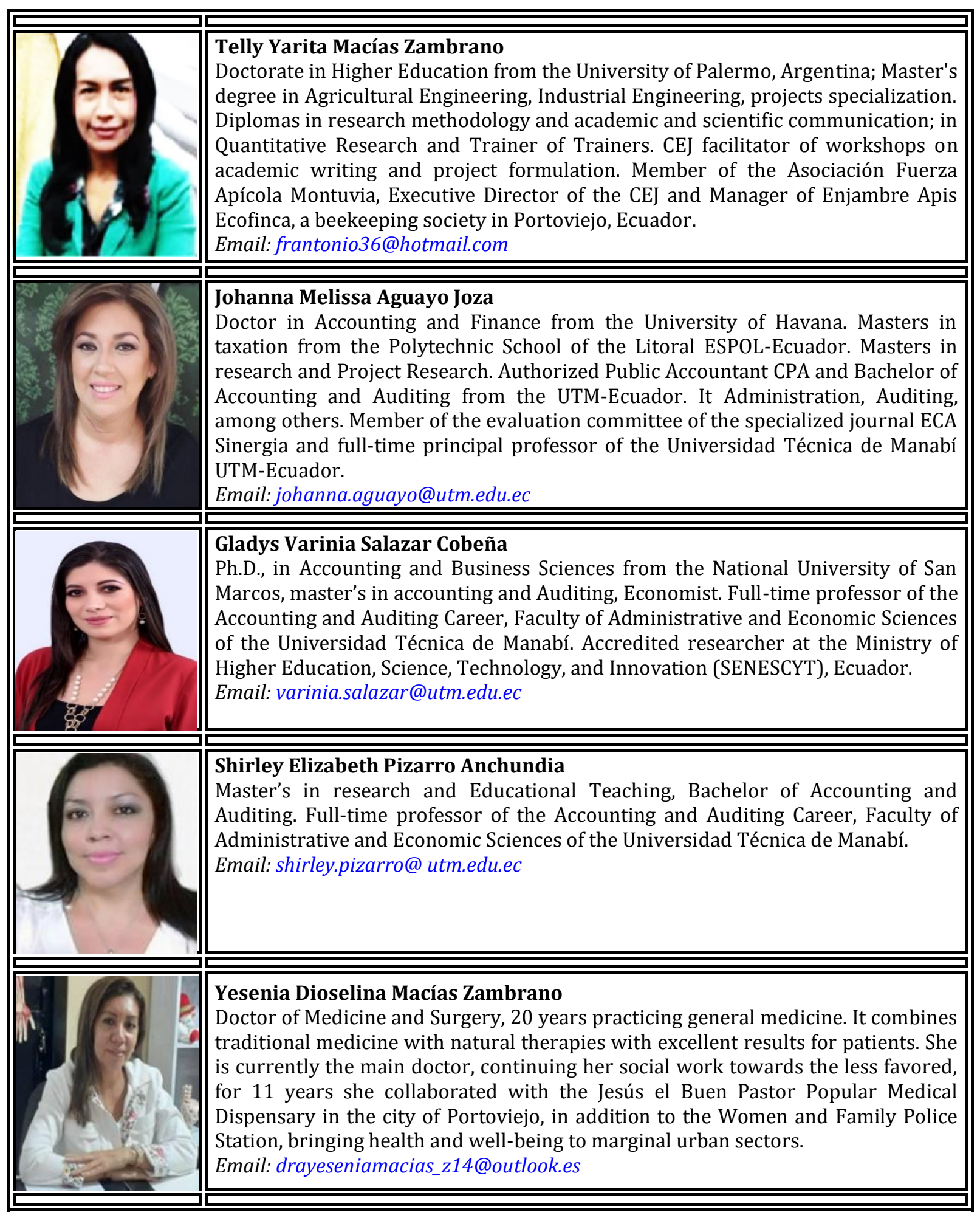

Zambrano, T. Y. M., Joza, J. M. A., Cobeña, G. V. S., Anchundia, S. E. P., \& Zambrano, Y. D. M. (2022). Honey, pollen and propolis in therapeutic treatments for COVID-19. International Journal of Health Sciences, 6(1), 196213. https://doi.org/10.53730/ijhs.v6n1.3766 